\title{
QUALITY OF LIFE AND ANXIETY IN MILITARY PERSONNEL
}

\author{
Aleksandra Vojvodic ${ }^{1}$, Gordana Dedic ${ }^{2}$
}

${ }^{1}$ Department of Dermatology and Venerology, Military Medical Academy, Belgrade, Serbia*,

${ }^{2}$ Clinic for Psychiatry, Military Medical Academy, Belgrade, Serbia; Faculty of Medicine of the Military Medical Academy, University of Defense, Belgrade, Serbia

\section{KVALITET ŽIVOTA I ANIKSIOZNOST KOD PROFESIONALNIH VOJNIH LICA}

\author{
Aleksandra Vojvodić ${ }^{1}$, Gordana Dedić ${ }^{2}$
}

${ }^{1}$ Odeljenje za dermatologiju i venereologiju, Vojnomedicinska akademija, Beograd, Srbija,

${ }^{2}$ Klinik za psihijatriju, Vojnomedicinska akademija, Beograd, Srbija; Medicinski fakultet Vojnomedicinske akademije, Univerzitet odbrane, Beograd, Srbija

\section{ABSTRACT}

The quality of life of military personnel represents their self-evaluation of the quality of their own mental and physical health, social relations, and the environment in which they live and work. The aim of our study was to evaluate the relationship between quality of life and anxiety levels in military personnel of the Serbian Armed Forces.

The cross-sectional study included a total of 311 randomly selected professional military personnel (officers, non-commissioned officers and professional soldiers) between 23 and 53 years of age (mean, 35.3 \pm 7 years) without current mental health problems. For the purpose of this study, we used the World Health Organization Abbreviated Instrument for Quality of Life Assessment (WHOQOL-BREF) and the Beck Anxiety Inventory (BAI). The statistical analysis included parametric and non-parametric descriptive statistics.

Professional military personnel showed high satisfaction with their quality of life in the categories of social relations (82.52), psychological health (82.10) and physical health (81.68), while the satisfaction scores in the category environment category were the lowest (62.77). The average value for

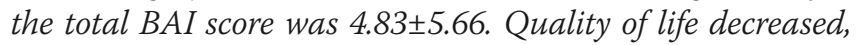
while anxiety increased, with increasing age of the military personnel. Higher BREF score values were associated with lower scores on the BAI questionnaires in all subscales $(p<0.001)$.

Military personnel of the Serbian Armed Forces showed a high degree of satisfaction with their own quality of life. Learning techniques to easily overcome everyday stress would reducedreduce anxiety and improve the quality of life in military personnel of the Serbian Armed Forces.

Key words: quality of life, anxiety, military personnel, Serbian Armed Forces

\section{SAŽETAK}

Kvalitet života profesionalnih vojnih lica predstavlja njihovu samoprocenu kvaliteta sopstvenog zdravlja kako psihickog tako i fizickog, kao i socijalnih odnosa i sredine u kojoj zive $i$ rade. Cilj našeg istraživanja bio je da proceni odnos između kvaliteta života $i$ nivoa anksioznosti profesionalnih vojnih lica Vojske Srbije.

Studija preseka obuhvatila je ukupno 311 profesionalnih vojnih lica (oficira, podoficira i profesionalnih vojnika) odabranih metodom slucajnog izbora, starosti izmedu $23 i$

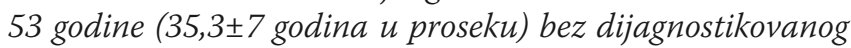
mentalnog problema. Za potrebe ove studije koristili smo Upitnik za procenu kvaliteta zivota Svetske Zdravstvene organizacije (skracena verzija) (WHOQOL-BREF) i Bekov upitnik za procenu anksioznosti (BAI). Statistička analiza uključivala je parametarsku i neparametarsku deskriptivnu statistiku.

Profesionalna vojna lica pokazala su veliko zadovoljstvo kvalitetom života u segmentima socijalnih odnosa (82,52), psihičkog zdravlja $(82,10)$ i fizičkog zdravlja $(81,68)$, dok je segment životne sredine bio najniži $(62,77)$. Prosečna vred-

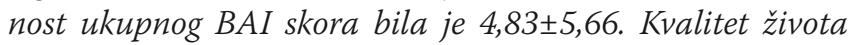
se smanjivao, dok se anksioznost povećavala sa godinama života vojnih lica. Visoke ocene BREF-a u svim domenima pratile su niže ocene BAI upitnika $(p<0,001)$.

Profesionalna vojna lica Vojske Srbije su pokazala visok stepen zadovoljstva svojim kvalitetom života. Tehnike učenja lakšeg prevladavanja svakodnevnog stresa dovele bi do smanjenja anksioznosti $i$ poboljšanja kvaliteta života profesionalnih vojnih lica Vojske Srbije.

Ključne reči: kvalitet života, anksioznost, profesionalna vojna lica, Vojska Srbije 


\section{ABBREVIATIONS}

QOL - Quality of life

WHO - World Health Organization

BREF or WHOQOL-BREF - World Health Organization Abbreviated Instrument for Quality of Life Assessment BREF 1 - How would you rate your quality of life? BREF 2 - How satisfied are you with your health?
DOM 1 - Physical Health

DOM 2 - Psychological Health

DOM 3 - Social Relations

DOM 4 - Environment

BAI - Beck Anxiety Inventory

SD - Standard deviation

\section{INTRODUCTION}

The military organization is a unique system characterized by a specific environment with an established system of work, in which the activity of an individual is regulated by rules and norms and the basic relationship is commanding. The structure of military units is hierarchical, and their operation is guided by rules of order and discipline $(1,2)$. Discipline, in the military context, is more than a requirement to obey the orders of a superior; it also involves following a set of general rules of behaviour, even in the face of distractions that include lethal threats. The emphasis on discipline serves two purposes: it facilitates the accomplishment of difficult missions, and it supports the creation and maintenance of spirit and morale. It is also characterized by specific symbolism of the military organization and commands, uniformity (uniformity of norms, behaviour, life and work clothes), accentuated ritualism (greetings, addressing, holding of the body), carrying a weapon, and other factors. $(2,3)$.

Military personnel face numerous stressors on a daily basis in their professional lives that affect their quality of life in the military environment. They are subject to the system of command, must respect the principle of subordination, undergo extreme training, etc., which may cause them to experience stress more frequently than the civilian population. At the same time, stressors in their family environment cannot be neglected $(4,5)$.

Quality of life (QOL) includes subjective well-being, life satisfaction, perceptions of social relationships, physical health, economic status, and functioning in daily activities and work (6). Quality of life is defined as an individual's perception of their position in life in the context of the culture and value systems in which they live and in relation to their goals, expectations, standards and concerns. The concept is very broad and includes variables related to one's physical health, psychological health, level of independence, social relationships and relationships to salient features of their environment (7).

In accordance with the above concepts, the quality of life of military personnel refers to their ability to engage in professional activities in the military environment and to participate in social activities, along with intrapsychic abilities that imply good health and psychological and intellectual functioning, both in the military environment and with their family $(3,4)$. Quality of life refers to the subjective experience of the quality of life of military personnel during professional military service, as opposed to the objective characteristics of the military environment (1). Social support is very important and may be a protective factor against the development of some psychological problems, including anxiety and depression, in poor working conditions (8).

Many studies have assessed the quality of life in different civilian environments or different aspects of illnesses (hypertension, migraine, diabetes) $(9,10)$; however, few of these studies were carried out in the military environment (3,11-14). In particular, no studies have investigated the relationship between job stress, anxiety and quality of life in the military environment.

The aim of our study was to evaluate the relationship between quality of life and anxiety levels in military personnel of the Serbian Armed Forces.

\section{METHODS}

A cross-sectional study was conducted in the three barracks of infantry units of the Serbian Armed Forces, whose total military personnel number met the required sample size of the respondents, and in which all military personnel were exposed to approximately the same professional burden. The study was conducted in September 2016.

This study was conducted with the approval of the Ethics Committee of the Faculty of Medical Sciences, University of Kragujevac. The study was approved by the General Staff of the Serbian Armed Forces. In addition, a special permit for the research in the units of the Serbian Armed Forces was obtained from the Ministry of Defense

\section{Subjects}

The study included a total of 311 randomly selected professional military personnel (officers, non-commissioned officers and professional soldiers), aged 23 to 53 years, who were on military duty for at least three years at a relatively high professional load, including duty service, guard duty, overtime work, or an inability to take days off. 
The sample was consecutive, i.e., participation in the study was offered to all members of the professional military unit who, during the study period, met the criteria for inclusion and exclusion. The inclusion criteria were as follows: subjects had to be professional military personnel of the Serbian Armed Forces (officers, non-commissioned officers and professional soldiers), work under a significant workload (guard, on-call, overtime, inability to use free days), be age 23 to 53 years, and have at least three years of active professional military service. The exclusion criterion was a diagnosed psychiatric illness.

Written informed consent was obtained from all participants prior to participation in the study, and the investigation included only those who volunteered to take part in it Thus, each respondent could drop out of the research if he or she felt that the questions in any way disturbed his or her mental well-being. All participants were assured anonymity and that only group-level findings would be reported.

The size of the sample was determined based on the formula for determining sample size. Ten percent was added to this number because of the possibility that questionnaires would not be fully completed. Using this method, we obtained a sample size of 311 respondents, with a previous decision to set the alpha error level at 0.05 and the beta level at the limit of 0.01 , which yields a study strength of $90 \%$ (15).

\section{Psychological instruments}

The demographic questionnaire included questions regarding age, gender, education, marital, professional and health status.

Psychometric assessments of quality of life and anxiety were made using the World Health Organization Abbreviated Instrument for Quality of Life Assessment (WHOQOL-BREF) (16) and the Beck Anxiety Inventory (BAI) (17).

The World Health Organization Abbreviated Instrument for Quality of Life Assessment (WHOQOL-BREF) is a self-report measure consisting of 26 items on a fivepoint Likert scale. This instrument was developed to measure physical, psychological, social and environmental aspects of subjective well-being. Domain scores were scaled in a positive direction (higher scores denote better QOL), with a score range of 4-20 that was transformed to a 0-100 scale following the standard procedure defined in the World Health Organization Abbreviated Instrument for Quality of Life Assessment user manual. The World Health Organization Abbreviated Instrument for Quality of Life Assessment could be applied cross-culturally. The World Health Organization Abbreviated Instrument for Quality of Life Assessment scores correlated strongly ( $\mathrm{r}$ $=0.89$ ) with the original WHOQOL - 100 domain scores. Permission to use the Serbian version was obtained from WHO (World Health Organization) (16).

The Beck Anxiety Inventory (BAI) is a non-specific, self-report inventory that is used for measuring the severity of anxiety in children and adults. The questions used in this inventory detect common symptoms of anxiety that the subject has experienced during the past week (including the day of the assessment). It served as the primary outcome for measuring the severity of anxiety in participants suffering from different primary anxiety disorders. The BAI assesses emotional, physiological and cognitive aspects of state anxiety. It consists of 22 items, rated on a four-point Likert scale ranging from $0=$ not at all to $3=s e-$ verely. Categorical anxiety levels consist of minimal (0-7 points), mild (8-15), moderate (16-25) and severe (26-63) anxiety (17).

\section{Statistical analyses}

Statistical analysis included parametric and non-parametric descriptive statistics, depending on the nature of data. Data analysis was carried out using SPSS software version 20.0.

To test whether all numerical parameters and scores were normally distributed, we used the KolmogorovSmirnov test. The results demonstrated that in all monitored and calculated parameters and scores there was a normal distribution ( $\mathrm{z}$ was less than 1.96 , and $\mathrm{p}<0.05$ ), so that it was possible to apply parametric methods in further analyses.

\section{RESULTS}

The demographic variables of the military personnel are shown in Table 1 . The average age of the professional military personnel was $35.3 \pm 7$ years. There were statistically significant differences in education and gender. There were more subjects with completed military education (military academy) (60.8\%) than with other categories of completed education $\left(\chi^{2}=8.167 ; \mathrm{p}<0.01\right)$, and the number of male subjects was much higher than the number of females $\left(\mathrm{X}^{2}=11.478 ; \mathrm{p}<0.01\right)$.

There was also a statistically significant difference in marital status $\left(\chi^{2}=8.167 ; \mathrm{p}<0.01\right)$; more military personnel were more married (62.7\%) than were in other marital status categories.

The presence of chronic somatic diseases (diabetes, hypertension, hypo/hyperthyrosis, migraine, etc.) was observed in a small number of subjects $(8,0 \%)$, who demonstrated statistically significant differences in the observed variable $\left(\chi^{2}=11.558 ; \mathrm{p}<0.01\right)$ compared to healthy subjects.

Table 1. Demographic characteristics of military personnel

\begin{tabular}{|l|c|c|c|}
\hline Variable & $\mathbf{\%}$ & $\mathbf{X}^{\mathbf{2}}$ & $\mathbf{P}$ \\
\hline Gender (male) & 91,3 & 11,478 & $<0.01^{* * *}$ \\
\hline Age (>30 years) & 79,5 & 5,598 & $<0.01^{* *}$ \\
\hline Education (>12 years) & 60,8 & 8,167 & $<0.01^{* *}$ \\
\hline Marital status (married) & 62,7 & 8,167 & $<0.01^{* *}$ \\
\hline Health status (somatic diseases presence) & 8,0 & 11.558 & $<0.01^{* * *}$ \\
\hline
\end{tabular}

*** $\mathrm{p}<0.01$ 
Table 2. Values of the total scores of the BREF and BAI questionnaires

\begin{tabular}{|c|c|c|c|c|c|}
\hline \multicolumn{2}{|c|}{ Questionnaire } & \multirow[t]{2}{*}{ Min } & \multirow[t]{2}{*}{$\operatorname{Max}$} & \multirow[t]{2}{*}{$\mathbf{X}$} & \multirow[t]{2}{*}{ SD } \\
\hline BREF & Domain & & & & \\
\hline & DOM 1 (Physical health) & 28.57 & 100.00 & 81.68 & 13.88 \\
\hline & DOM 2 (Psychic health) & 29.16 & 100.00 & 82.10 & 13.23 \\
\hline & DOM 3 (Environment) & 9.37 & 100.00 & 62.77 & 17.81 \\
\hline & DOM 4 (Socail relathionship) & 41.67 & 100.00 & 82.52 & 12.29 \\
\hline & BREF 1 - How would you rate your quality of life? & 1.00 & 5.00 & 3.61 & 0.84 \\
\hline & BREF 2 - How satisfied are you with your health? & 2.00 & 5.00 & 4.06 & 0.77 \\
\hline BAI & & 0.00 & 39.00 & 4.83 & 5.66 \\
\hline
\end{tabular}

WHOQOL-BREF (World Health Organization Abbreviated Instrument for Quality of Life Assessment) BAI (Beck Anxiety Inventory)

The total scores on the BREF domains and BAI questionnaire are shown in Table 2. The results of the BREF questionnaire showed approximately the same values for the domains of Psychological Health, Physical Health and Social Relations, while the scores were the lowest for the Environment domain. The average value for total BAI score was $4.83 \pm 5.66$.

The average values for the total BAI score increased with the age of the military personnel, and a strongly statistically significant difference was detected between respondents of differing ages $(\mathrm{p}<0.001)$ (Table 3$)$.

The average total BREF scores decreased with the age of the respondents. Strongly statistically significant differences were found for Psychiatric Health and the Social Environment $(\mathrm{p}<0.001)$, as well as for Physical Health $(\mathrm{p}<0.05)$ (Table 3).

In the total BREF scores of all domains, the highest average values were observed in subjects with minimal anxiety levels, followed by individuals with a mild level of anxiety. The lowest average total BREF scores were reported by respondents with moderate and high levels of anxiety. In all situations, the BREF questionnaire values were negatively linked to the mentioned scores, indicating that higher BREF scores in the respondents were associated with lower scores on the BAI questionnaires. There were strongly statistically significant differences among all subjects $(\mathrm{p}<0.001)$ (Table 4$)$.

There were statistically significant differences between the total score on the BREF question 1 (How would you rate your quality of life?) and the individual BREF questionnaires for Social and Physical Health $(\mathrm{p}<0.001)$, as well as for the Environment and Psychological Health domains $(\mathrm{p}<0.05)$.

There were statistically significant differences between the total score on the BREF question 2 (How satisfied are you with your health?) and the individual BREF question-

Table 3. Correlation of BREF and BAI total scores according to the age of military personnel

\begin{tabular}{|c|c|c|c|c|c|c|c|}
\hline \multicolumn{2}{|c|}{ Questionnaire } & $\begin{array}{c}\text { Age } \\
\text { (years) }\end{array}$ & $\mathbf{N}$ & $\mathbf{X}$ & SD & $\mathbf{F}$ & $\mathbf{p}$ \\
\hline \multirow{3}{*}{\multicolumn{2}{|c|}{ BAI }} & $<30$ & 98 & 3.99 & 3.69 & \multirow{3}{*}{$6.820^{*}$} & \multirow{3}{*}{$0.001^{* * *}$} \\
\hline & & $31-40$ & 140 & 4.34 & 5.63 & & \\
\hline & & $>40$ & 73 & 6.92 & 7.26 & & \\
\hline \multirow{12}{*}{ BREF } & \multirow{4}{*}{$\begin{array}{l}\text { DOM } 1 \\
\text { (Physical health) }\end{array}$} & $<30$ & 98 & 83.34 & 12.81 & \multirow{3}{*}{4.204} & \multirow{3}{*}{$0.016^{*}$} \\
\hline & & $31-40$ & 140 & 82.63 & 13.11 & & \\
\hline & & $>40$ & 73 & 77.64 & 15.96 & & \\
\hline & & $<30$ & 98 & 84.27 & 12.87 & \multirow{3}{*}{6.939} & \multirow{3}{*}{$0.001 \% * *$} \\
\hline & \multirow{2}{*}{$\begin{array}{l}\text { DOM } 2 \\
\text { (Psychic health) }\end{array}$} & $31-40$ & 140 & 83.12 & 12.04 & & \\
\hline & & $>40$ & 73 & 77.23 & 14.80 & & \\
\hline & \multirow{3}{*}{$\begin{array}{l}\text { DOM } 3 \\
\text { (Environment) }\end{array}$} & $<30$ & 98 & 84.78 & 10.64 & \multirow{3}{*}{9.388} & \multirow{3}{*}{$0.001^{* * \%}$} \\
\hline & & $31-40$ & 140 & 83.69 & 11.82 & & \\
\hline & & $>40$ & 73 & 77.28 & 13.84 & & \\
\hline & \multirow{3}{*}{$\begin{array}{l}\text { DOM } 4 \\
\text { (Social relathionship) }\end{array}$} & $<30$ & 98 & 63.65 & 16.74 & \multirow{3}{*}{0.819} & \multirow{3}{*}{0.442} \\
\hline & & $31-40$ & 140 & 63.37 & 17.51 & & \\
\hline & & $>40$ & 73 & 60.45 & 19.72 & & \\
\hline
\end{tabular}

BAI (Beck Anxiety Inventory)

WHOQOL-BREF (World Health Organization Abbreviated Instrument for Quality of Life Assessment)

**** $\mathrm{p}<0.001$

*p $<0.05$ 
Table 4. Correlation of the total scores of BAI and BREF questionnaires

\begin{tabular}{|c|c|c|c|c|c|c|}
\hline BREF & $\begin{array}{c}\text { BAI } \\
\text { Level }\end{array}$ & $\mathbf{N}$ & $\mathbf{X}$ & SD & $\mathbf{F}$ & $\mathbf{P}$ \\
\hline \multirow{4}{*}{$\begin{array}{l}\text { DOM } 1 \\
\text { (Physical health) }\end{array}$} & Minimal & 275 & 84.04 & 13.41 & \multirow[t]{4}{*}{49.619} & \multirow[t]{4}{*}{$0.001^{* * *}$} \\
\hline & Mild & 19 & 69.55 & 15.04 & & \\
\hline & $\begin{array}{l}\text { Moderate/ } \\
\text { severe }\end{array}$ & 17 & 57.14 & 14.35 & & \\
\hline & Total & 311 & 81.68 & 15.54 & & \\
\hline \multirow{4}{*}{$\begin{array}{l}\text { DOM } 2 \\
\text { (Psychic health) }\end{array}$} & Minimal & 275 & 84.17 & 11.04 & \multirow[t]{4}{*}{36.349} & \multirow[t]{4}{*}{$0.001^{* * *}$} \\
\hline & Mild & 19 & 70.17 & 13.21 & & \\
\hline & $\begin{array}{l}\text { Moderate/ } \\
\text { severe }\end{array}$ & 17 & 62.50 & 15.68 & & \\
\hline & Total & 311 & 82.10 & 12.70 & & \\
\hline \multirow{4}{*}{$\begin{array}{l}\text { DOM } 3 \\
\text { (Social relathionship) }\end{array}$} & Minimal & 275 & 83.78 & 11.21 & \multirow[t]{4}{*}{13.588} & \multirow[t]{4}{*}{$0.001 \%$} \\
\hline & Mild & 19 & 74.93 & 17.85 & & \\
\hline & $\begin{array}{l}\text { Moderate/ } \\
\text { severe }\end{array}$ & 17 & 71.02 & 13.46 & & \\
\hline & Total & 311 & 82.01 & 12.90 & & \\
\hline \multirow{4}{*}{$\begin{array}{l}\text { DOM } 4 \\
\text { (Environment) }\end{array}$} & Minimal & 275 & 64.79 & 11.21 & \multirow[t]{4}{*}{17.627} & \multirow[t]{4}{*}{$0.001^{* * *}$} \\
\hline & Mild & 19 & 50.32 & 16.19 & & \\
\hline & $\begin{array}{l}\text { Moderate/ } \\
\text { severe }\end{array}$ & 17 & 43.94 & 15.51 & & \\
\hline & Total & 311 & 62.77 & 17.81 & & \\
\hline
\end{tabular}

BAI (Beck Anxiety Inventory)

WHOQOL-BREF (World Health Organization Abbreviated Instrument for Quality of Life Assessment)

*** $\mathrm{p}<0.001$

naires for Social Relations $(\mathrm{p}<0.001)$, as well as for Psychic Health and Physical Health domains $(\mathrm{p}<0.005)$ and Environment $(\mathrm{p}<0.05)$.

\section{DISCUSSION}

In this study, we wanted to determine how job strain in the military environment affects anxiety and quality of life. Individuals in some professions, such as firefighters, rescue professionals and military professionals, deserve special attention regarding health care because they are exposed to extreme physical, mental and social demands in their daily work and, therefore, are susceptible to different health risks $(3,18)$. Studies have reported that in the military environment, stress arises from risky assignments or missions, problems in interactions with peers and those of higher rank, sleep deprivation from shift work, the demand for physical fitness, deployment and separation from family, and additional noncombat work assignments such as disaster relief, peacekeeping and other humanitarian actions $(2,9,11)$.

Pearlini and Schooler described four primary social roles: marital, parental, professional and domestic (19). Problems with maladaptation to the military environment contribute to the simultaneous presence of several problems related to these roles, as well as their mutual conflict $(2,11)$.
According to some studies, marital situation is an important factor that may be associated with individuals' quality of life $(2,6,20,21)$. In our study, approximately $2 / 3$ of the military personnel were married, and many families included children. Domestic problems with children and spouses have an important impact on the professional lives of military personnel. The downsizing of military manpower and budget cuts increase the workload and stress levels of the few remaining military personnel. Family support is a top priority. The US Army has established exclusive programs addressing every aspect of family life to help service members and their loved ones. Some examples of such programs include affordable family housing, military spouse education, child care, affordable shopping, youth education and development, family health care, family advocacy, services for families with special needs, family citizenship, family recreation, financial stability, family relocation and family counselling. The aim of these programs is to maximize service member families' stability and quality of life (22).

In accordance with other studies, we found that the respondents reporting a significantly high average quality of life were younger and healthier. Their perception of quality of life was significantly better that of thefor younger than for older respondents; this finding was expected because the younger respondents did not have chronic diseases, were psychologically and physically healthy and experienced good social relations (3). In our study, physical health, that 
is, the absence or the presence of chronic disease, proved to be the most important factor affecting all segments of quality of life as well as anxiety. This finding was expected and is in line with the results of other investigations (23-25).

The anxiety levels measured using the BAI questionnaire were significantly higher in older respondents, as well as in respondents with chronic somatic illnesses. These findings were expected, given that those respondents have experienced stress and overwork for many years and have become worn out over time. This observation has been demonstrated in other studies $(3,26,27)$.

Respondents with higher anxiety reported significantly lower perceptions of quality of life in all categories; this finding emphasizes how strongly stress and consequent anxiety broadly affect the life and functioning of individuals $(7,11,14)$.

In our study, among the four domains of the WHOQOL-BREF, the highest mean satisfaction rating was found for DOM 3 (Social Relationships), implying good interpersonal relationships. This observation is of exceptional significance for the military environment in peacetime, and is even more important during wartime conditions. Interpersonal relations in the military reflect the nature of the military activity, the character of the society to which the military belongs, the complexity of the work with combat techniques, the special conditions of the work, and the military subordination. Each member of the military collective was in an interactive relationship, i.e., interacting with other members of that collective. The cohesiveness and efficiency of the military unit depends on the quality of interpersonal relations. Cohesiveness is expressed through feelings of belonging and loyalty to the collective, an atmosphere of security, the ability to establish friendly relationships, emotional relationships, and well-structured time. The social domain evaluates issues related to personal relationships, sexual activity, practical social support, and feelings of being respected and accepted. Adverse social relationships and job characteristics have been associated with poorer health, and some studies have found that social support may act as a buffer and protect against the development of depression or anxiety in environments with poor working conditions $(4,5,9,11,14)$

Because this was a primarily healthy study population, it was expected that scores would be high for DOM 1 (Physical Health), which measures self-assessment of satisfaction with one's own physical health. High scores were also reported for DOM 2 (Psychological Health), which was expected in a military environment where people are prepared to deal with stressful situations on a daily basis and are ningtrained under extreme conditions (28).

Our study showed that mental health, including anxiety and social relationships, but not physical health, was impaired most strongly in older military personnel. Therefore, the relationship between quality of life and health perception is crucial for the sustained prosperity of military personnel and the strength of troops (29). Emotional distress significantly affects the combat readiness and opportunities of the individual and thus the entire army (4).
The environmental domain was an important issue in the workplace $(6,4)$. Moreover, the lowest mean score was shown for DOM 4 (Environment). This finding was expected due to poor working conditions, unsolved housing issues and low salaries. Social support is very important and may be protective against the development of anxiety and depression under adverse working conditions (3, 6). Mental and physical health undoubtedly have a strong impact on overall quality of life and are significantly influenced by stress at work. Individuals with a higher rank and positions with greater accountability are more vulnerable to the effects of stressors $(2,9,30)$.

In DOM 4, there were different variations in responses (SD very high) among groups. This variation may be associated with different social groups, where those who had a real-life housing or income issue or were out of work were likely to be more satisfied with the environment $(2,6)$.

There was no statistically significant difference in responses based on gender and marital status. Women in the military environment have a similar perception as their male colleagues in all domains of quality of life. They bear the same professional burdens as men, but also have obligations in other social roles, primarily marital $(5,8,11)$.

\section{CONCLUSION}

In spite of the many stressors and high demands at work, military personnel of the Serbian Armed Forces reported a high degree of satisfaction with their own quality of life, especially in the fields of psychological and physical health and social relations. Learning techniques to easily overcome everyday stress would lead to a reduction in anxiety and improve the quality of life of military personnel of the Serbian Armed Forces.

\section{LIMITATIONS}

The published data were approved by the competent authorities. We did not have approval to obtain other information that might be relevant to the study, such as the military rank of the members and the formation position. Also, the sample was composed primarily of men, which is a limitation that could not be overcome.

\section{REFERENCES:}

1. Dedić G. (2001). Prilagodjavanje vojnika na vojnu sredinu. Beograd: Novinsko-izdavački centar Vojska.

2. Dedić G, Kostić P. (2001). Uzroci frustracije u periodu adaptacije vojnika na vojnu sredinu. Vojnosanit Pregl. 58(6), 621-630.

3. Dedić G. (2003). Kvalitet života vojnika u periodu adaptacije na vojnu sredinu. Vojnosanit Pregl. 60(3),305-314. 
4. Pflanz SE, Ogle AD. (2006). Job stress, depression, work performance, and perceptions of supervisors in military personnel. Mil Med. 171(9),861-865.

5. Plaisier I, de Bruijn JG, de Graaf R. (2007). The contribution of working conditions and social support to the onset of depressive and anxiety disorders among male and female employees. Soc Sci Med. 64,401-410.

6. Angermeyer M, Kilian R, Wilms HU. (2006). Quality of Life of Spouses of Mentally Ill People. Int J Soc Psychiatry. 52(3),278-285.

7. Karimi M, Brazier J. (2016). Health, Health-Related Quality of Life, and Quality of Life: What is the Difference? Pharmacoeconomics. 34(7),645-9.

8. Dedić G. (2004). Socijalno prilagodjavanje vojnika za vreme vojnog roka; Vojnosanit Pregl. 61(6),637-643.

9. Airila A, Hakanen JJ, Luukkonen R, Lusa S, Punakallio A. J. (2013). Positive and negative mood trajectories and their relationship with work ability, self-rated health, and life satisfaction: a 13-year follow-up study. Occup Environ Med. 55(7), 779-785.

10. Levin L, Zini A, Levine J, Weiss M, Lev RA, Hai A, Chebath-Taub D, Almoznino G. (2017). Dental anxiety and oral health-related quality of life in aggressive periodontitis patients. Clin Oral Investig. doi: 10.1007/ s00784-017-2234-8.

11. Plaisier I, de Bruijn JG, de Graaf R. (2007). The contribution of working conditions and social support to the onset of depressive and anxiety disorders among male and female employees, Soc Sci Med. 64,401-410.

12. Van Eetveldt MW, van de Ven N, van den Tooren $M$, Versteeg RC. (2013). The Importance of Career Insecurity for Turnover Intentions in the Dutch Military. Milit Psychol. 25(5), 489-501.

13. Tzeng DS, Chung WC, Yang CY. (2013). The effect of job strain on psychological morbidity and quality of life in military hospital nurses in Taiwan: a follow-up study. Ind Health. 51(4), 443-51.

14. McDougall L, Drummond PD. (2010). Personal resources moderate the relationship between work stress and psychological strain of submariners. Military Psychology. 22(4), 385-398.

15. Erić-Marinković J, Dotlić R, Janošević S, Kocev N, Gajić M, Ille T, Stanisavljević D, Babić D. (2011). Statistika za istraživače u oblasti medicinskih nauka, Beograd: Medicinski fakultet.

16. WHOQOL Group. (1998). Development of the World Health Organization WHOQOL-BREF quality of life assessment. Psychol Med; 28 (3), 551-558

17. Beck AT, Brown G, Epstein N, Steer RA. (1988). An Inventory for Measuring Clinical Anxiety: Psychometric Properties. Journal of Consulting and Clinical Psychology. 56, 893-897.
18. Katsavouni F, Bebetsos E, Malliou P, Beneka A. (2016). The relationship between burnout, PTSD symptoms and injuries in firefighters. Occup Med (Lond). 66(1), 32-7.

19. Leonard I. Pearlin and Carmi Schooler. (1978). The Structure of Coping. Journal of Health and Social Behavio. 19(1), 2-21.

20. Santini ZI, Koyanagi A, Tyrovolas S., Haro JM. (2015). Association of relationship quality and social networks with depression, anxiety, and suicidal ideation among older married adults: Findings from a cross-sectional analysis of the Irish Longitudinal Study on Ageing (TILDA) J Affect Disord. 179,134-41

21. Davis BE, Blaschke GS, Stafford EM. (2012). Military children, families, and communities: supporting those who serve. Pediatrics.129 Suppl 1,S3-S10.

22. Oznur T, Akarsu S, Erdem M, Durusu M, Toygar M, Poyrazoglu Y, Kaldirim U, Eryilmaz M, Ozmenler KN. (2015). Psychiatric Symptoms and Quality of Life in Military Personnel Deployed Abroad. Isr J Psychiatry Relat Sci. 52(3),60-4.

23. Han-Wei C, Wen-Chii T,Yu-Ching C, Hui-Wen Y, HsinAn C, Yu-Cheng K, Nian-Sheng T. (2014). Psychological morbidity, quality of life, and self-rated health in the military personnel. Neuropsychiatric Disease and Treatment..10 (29),338.

24. Schlichting A, Schlichting J, Gutierres Filho P, Adami F, Silva A. (2012). Aspects related to quality of life and physical activity of military police officers of Santa Catarina - Brazil. Motricidade.8(3),81-89.

25. Luncheon C, Zack M. (2012). Health-related quality of life among US veterans and civilians by race and ethnicity. Prev Chronic Dis. 9, E108.

26. Lovering ME, Proctor SP, Heaton KJ. (2013). A retrospective study of anxiety disorder diagnoses in the military from 2000 to 2009. Journal of Anxiety Disorders. 27(1), 25-32.

27. Pan Y, Cai W, Dong W, Xiao J, Yan J, Cheng Q. (2017). Behavior characteristics of the attention network of military personnel with high and low trait anxiety. Bush. E, ed. Medicine. 96(17):e6630.

28. Petersen C, Rush SC, Gallo I, Dalere B, Staak B, Moore L, Kerr W, Chandler M, Smith W. (2017). Optimization of Simulation and Moulage in Military-Related Medical Training. J Spec Oper Med. 17(3), 74-80.

29. Puciato D, Borysiuk Z, Rozpara M. (2017). Quality of life and physical activity in an older working-age population. Clin Interv Aging. 4(12), 1627-1634.

30. Racic M, Todorovic R, Ivkovic N, Masic S, Joksimovic B, Kulic M. (2017). Self- Perceived Stress in Relation to Anxiety, Depression and Health-related Quality of Life among Health Professions Students: A Crosssectional Study from Bosnia and Herzegovina. Zdr Varst. 56(4), 251-259. 
$\$$ sciendo 